\title{
Sustainable Environment Education in Pre-School Pupils
}

\author{
Cimen Ozburak ${ }^{1 *}$, Mehmet Harun Batırbaygil ${ }^{2}$, Semra Sema Uzunoğlu ${ }^{1}$ \\ ${ }^{1}$ Near East University, Nicosia, CYPRUS \\ ${ }^{2}$ Cankaya University, Ankara, TURKEY
}

Received 11 February 2018 - Revised 10 May 2018 - Accepted 15 May 2018

\begin{abstract}
"Sustainable Environmental Education" at early ages is important for creating environmental awareness. When the content of current environmental education curriculums at schools in the North Cyprus is analyzed, it is seen that only the natural environment elements are covered. Whereas environment is divided into two that are natural and the built environment. Besides the recognition and protection of the natural environment, sustainable built elements play an important role. The aim of this study is to identify through measuring the deficiency of preschool children's level of awareness of "sustainable built environment". The study was administered to 134 five year-old preschool children at a private school in the city of Nicosia by using the qualitative approach. During the study, "Interviews" were arranged and 17 questions were asked to the children. The children's level of knowledge on "sustainable built environment" was measured through a pre-test. According to the results obtained, the children are familiar with natural elements such as the trees, animals and water around their environment but are not familiar with basic building elements or related sustainable systems such as wind turbine (25.37\%), solar panels $(13.43 \%)$ and green roof $(8.20 \%)$. These results show us the the lack of "sustainable built environment education".
\end{abstract}

Keywords: preschool, sustainable environment education, built environment

\section{INTRODUCTION}

Today children are distancing themselves from nature more and more due to the effects of the urbanization. According to the data of the United Nations Population Department, by 2025, in developing countries, 10 out of 6 children will be obligated to live in urbanized areas (Tandoğan, 2014). Whereas humans are part of nature and are inseparable. Making good relations with nature depends on people's understanding. Therefore, the suitable time for this is early childhood period. The reason for this is the information obtained in this period will influence their future lives (Kavak \& Coşkun, 2017). Neurological explanations are also possible for this.

In short, the human brain is formed of the upper brain straight below is the subconscious and lower brain. Humans are born with four million years of knowledge about the universe in their lower brain. The very first information learned is formed through the upper brain and it's reserved in the subconscious. This period lasts until approximately the age of six where the subconscious is closed and the upper brain becomes active. Before the subconscious is closed, the knowledge gained within the six-year period is important and has an effect on the human throughout life (Çukur \& Özgüner, 2008). For this reason, the study group we chose for the research is preschool children at the age of five who have not yet reached the age of six.

Educationist very effective to determine the quality of life for an individual in the society. The place and building in which education takes place constitutes good habitual materials (İslamoğlu, 2017). In this context in the preschool period, education integrates with environment to form awareness towards environment in the future as fundamentals of "willing behaviour" (Erten, 2004). Sontay, Gökdere, and Usta (2014), in their study, mentioned

(C) 2018 by the authors; licensee Modestum Ltd., UK. This article is an open access article distributed under the terms and conditions of the Creative Commons Attribution License (http://creativecommons.org/licenses/by/4.0/). \.imen.ozburak@neu.edu.tr cozburak@hotmail.com (*Correspondence) $\square$ harunbatirbaygil@cankaya.edu.tr \sema.uzunoglu@neu.edu.tr 


\section{Contribution of this paper to the literature}

- Emphasizing the awareness of environmental education at preschool which is divided into two, "natural and built" environment.

- To provide awareness of children's knowledge about architecture at early age in preschool environment.

- By emphasizing the awareness of the "educational role" of the school buildings, children are encouraged to use the buildings for environmental education.

- To provide children with the recognition of the built environment within the school environment through "playing games".

- Not using technological development but providing the opportunity of learning through "sustainable built environment".

about the environmental education taught to secondary school children and stated that this education should have been taught at earlier years.

Considering that the children spend most of their time at school, the knowledge they receive about nature at these early ages is extremely important (Kahyaoğlu \& Yetişir, 2015). According to many researches including Nikolaeva (2008), environmental education received within the school discipline ensures results that are more positive. Basile's (2000) research also confirms this and it is stated in the study that the consciousness towards the environment begins to take shape in preschool period. In this period, for children, the level of education and desire especially based on observations is higher.

It is insufficient when environmental education includes only natural elements. The program should be completed by including the architectural, built environment elements. The reason for this is that the environment consists of two parts that are "natural and built". The built environmental education for children will not only teach them the building but also help them to form the strong connection with the environment (Gökmen, 2010).

It is important that the built environment education is given in formal way by integrating the curriculum in the school environment. Historically, it is known that Jaus referred to environmental education for the first time in the preschool period in 1982 (Taşkın \& Şahin, 2008). When the current literature on the subject is studied, it is observed that studies that emphasize the importance of "built environment" education are carried out by occupational chambers. For example, International Architects Union (IAU) undertook studies whereas intense studies began in 2002 in Turkey in Ankara by the Chambers of Architects. Both these establishment's aims were to transfer the meaning of urbanity, perception of places and facts of habitable environment to the children (Chamber of Architects Ankara Branch). To this day in general in TRNC, European Union funding projects have been conducted and this still continues. For example, the study named "Children Awareness of Energy and Environment Project" is one of the long-term studies conducted until March 2017, which is an applied project, funded by the EU (European Union) and supported together with the Chambers of Environment and Electrical Engineers (Gündem Kibris, 2015, February 11).

In the early years of the children, it is very effective that in preschool education the children brought up are respectful in the habitat in which they live in. Preschool education institutes must ensure that the children contribute an aspect in protecting the nature and environment, have knowledge and awareness of the process of nature recycling and natural occurences (Klaar \& Öhman, 2014).

While trying to adapt built environment awareness, the target age group should be well recognized and appropriate training methodologies should be selected (Green, 2015). In the study of Warburton (2003) drew attention by stating that in schools, environment education must be taught through using some materials. Besides, children learn through games (Sar1, 2011). By using the game method, suitable activity programs must be formed (Gülay \& Öznacar, 2010). In this system, where children learn by playing, participating, and practicing, environmental education itself is sustainable and can take a permanent place in school curriculum (Özdemir, 2007).

In the context of learning mostly the development of environment recognition of interior places in preschool education carries importance as much as activities on exterior places (Cooper, 2015). In the study of Miller (2007) conducted in Lincoln-Nebraska, developed a current preschool education institute and named it as "Exterior classroom" and mentioned about the design and activities within this area. This area included a garden and greenhouse that the children raised and maintained vegetables, fruits, flowers and other types of plants, at the same time it was designed as an area that the children could play in. In open-air activities physical development, health, creativity and productivity type of subjects have an effect on the children. In context, school gardens and landscape designs carry a big importance. There should be a design which children can respond to learning impulse, contains different forms, is suitable for anthropometric shapes and children will be able to learn different plant and animal species. (Çukur, 2011). Alongside to all this, the factor of teachers and family must be taken into consideration during the education of built environment. Besides the attributes of the "environment education" program in the 


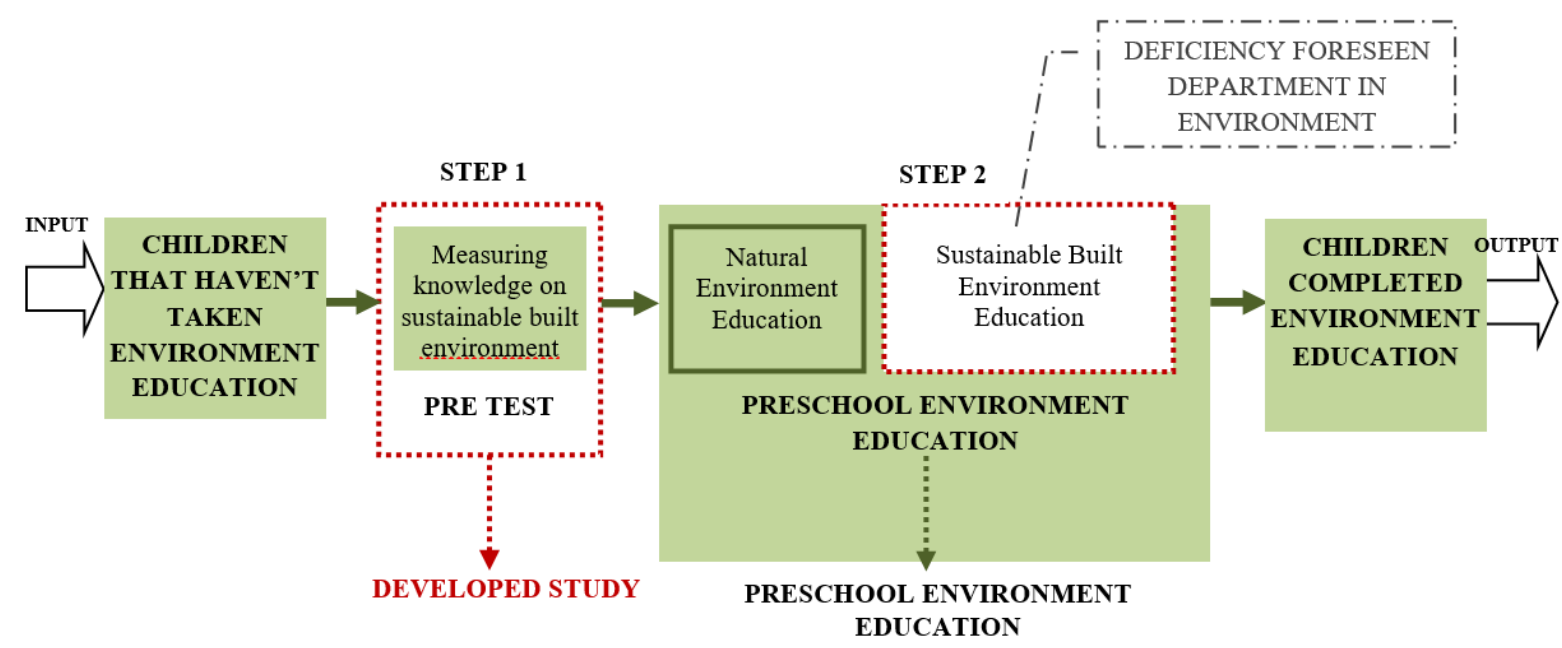

Figure 1. Diagram of preschool "environment education" content and mechanism

school environment, the role of the educator is major. As stated in the study of Esa (2010), it is necessary that in every level of education the most effective stakeholders which are the teachers must have sufficient knowledge to acquire the correct environment and sustainable awareness to the pupils within this area. On the other hand, Musser and Diamond (1999) emphasized that preschool children receiving environment education at school is as important as it is with contributions on environment education at home.

Considering today's environment issues, it will be insufficient only to include "built environment" in the education program. In the study of Kahriman-Öztürk, Olgan, and Guler (2012), the term of recycling, reducing the natural resources (such as energy / water) used, and the importance of respecting nature, must be transferred to individuals in early childhood. In context, the study aims to focus on preschool period of "sustainable built environment" education. The primary aim of current programs focusing on "natural environment" education, is to state the deficiency of children's awareness on "sustainable built environment".

\section{METHOD}

In preschool period, it is thought that environmental education given to schools is only aimed at learning and protecting "natural life". The environment, however, is not just about nature. The human-generated environment lies within and interacts with the natural environment.

This study was conducted with the aim of measuring the "sustainable built environment" knowledge levels of 5 -year-old children as built environment education has not yet entered school curriculum. The content and mechanism of the environment education program is shown as in the diagram Figure 1. A pre-test was administered to the children who have not yet taken the "environment education program" (step 1). In the preschool period as seen suitable in the environment education "natural" and "sustainable built environment" elements should be taught together (step 2). In this study, by using the results obtained by the pretest, in the preschool period the deficiency for "environment education program" has been identified.

This study was administered with participants of 5-year-old children studying at a private preschool. In the preschool period, the children have not yet gained reading and writing abilities. For this reason a qualitative research method for this study was administered through interviews. The interview questions were prepared in two types as "closed-ended questions" and "open-ended questions". This method was applied to obtain more rich and detailed data in order not to restrict the children with their thoughts (Böke, 2009). The questions were prepared by taking into consideration LEED "The Leadership in Energy and Environmental Design" green building certificate system that is formed of five primary criteria in order to be able to measure the level of knowledge on sustainable built environment (the fifth criterion was left out as five year old children's perception level was not found suitable). As seen in Table 1 "LEED - Green Building Certificate System" criteria are according to the buildings sustainable features that make points and is part of the worlds most extensive system (USBGC, 2014). 
Table 1. "Pre-Test" questions distribution table in context to the LEED Certificate Criteria PRE-TEST QUESTION DISTRIBUTION ACCORDING TO THE CONTEXT OF LEED GREEN CONSTRUCTION CRITERIA CERTIFICATE SYSTEM

\begin{tabular}{lll}
\hline 1 & Sustainable Sites & 5 questions \\
\hline 2 & Water Efficiency & 3 questions \\
\hline 3 & Energy Efficiency & 4 questions \\
\hline 4 & Evaluation of waste materials & 5 questions \\
\hline 5 & Indoor Quality & $\begin{array}{l}\text { This criterion was not found suitable for } 5 \text { year old child's perception therefore an } \\
\text { activity wasn't formed. }\end{array}$ \\
\hline TOTAL OF 17 QUESTIONS & \\
\hline
\end{tabular}

Table 2. Interview questions for the children according to the LEED criteria

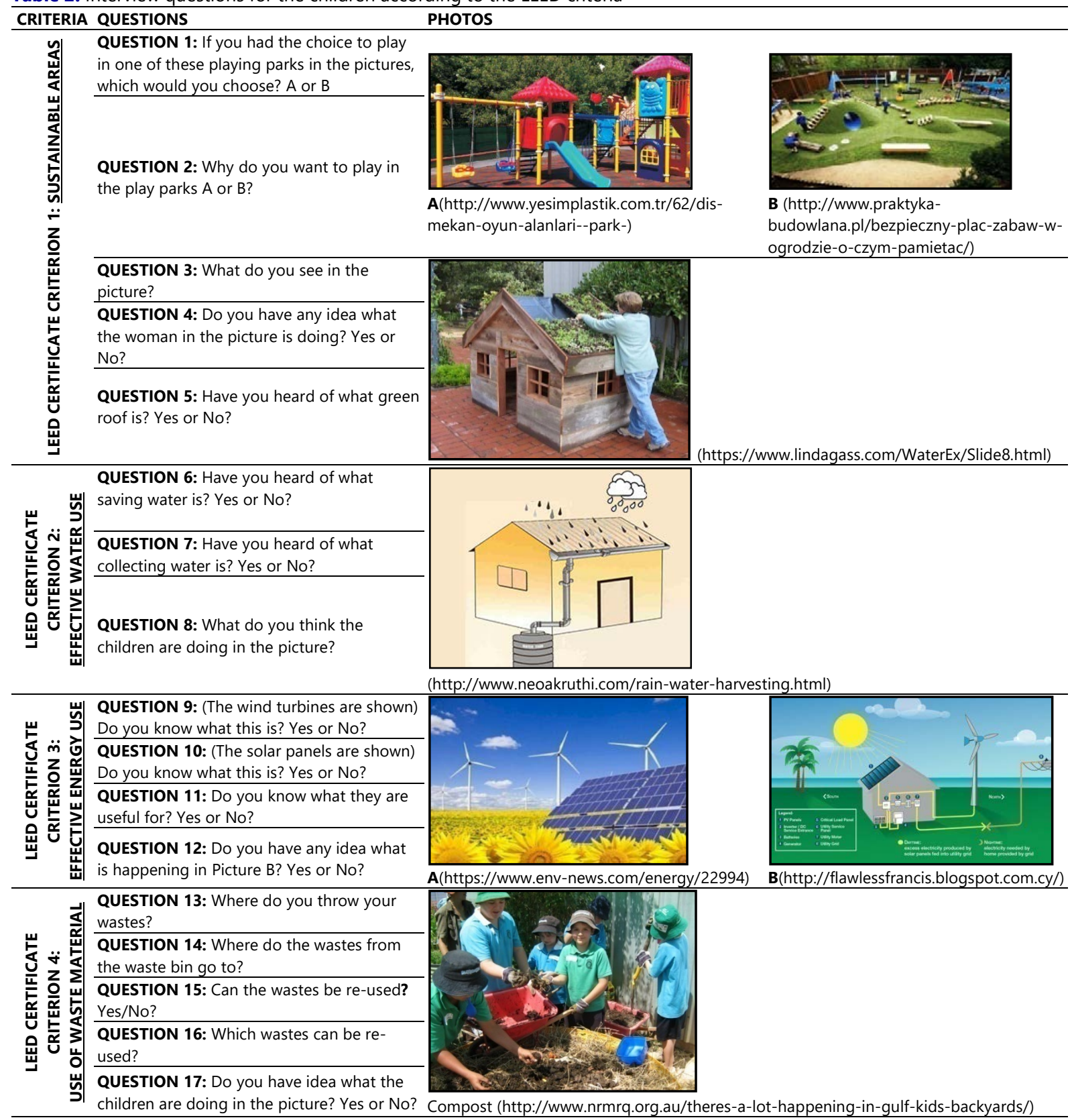

The interviews with the children were conducted face to face in their own classroom environment. A total of 134 pupils from eight classes were interviewed. The interviews were completed and carried out with two experts within the field of architecture in two weeks under the supervision of the classroom teachers. The interview questions were administered after the approval of the school's education coordinator.

The children were asked 17 questions with pictures. The LEED Certificate Criteria are grouped questions as seen in Table 2. 
In the early childhood period, it is important whilst making studies on measuring and evaluation that the interviewer should have a smiley face and fearless behavior towards the child (Erdoğan \& Canbeldek, 2017). The children should feel safe and comfortable. In addition, a separate station was formed in the classroom of the children to carry out the interviews. Therefore, the answers they will give will show no effect on each other. The administered interviews were recorded. So that the reliability is kept high, the given data is reflected on the report exactly the same way as the data was given as in the Walcott method (descriptive analysis method) (Gürbüz \& Şahin, 2014).

Data analysis: The data obtained from the pretest was evaluated in 4 separate criteria according to the LEED Green Building Certificate System. The open-ended questions for "sustainable built environment" data were formed in 3 step codes as awareness motion, unawareness motion and undecided. While the given data is being processed, the number of pupils (n) and success percentage (\%) was stated.

$$
\text { Success percentage }=\frac{\frac{\text { level of awareness motion }}{\text { unawareness motion }}}{\frac{\text { awareness motion }}{\text { unawareness motion }}+\text { undecided }(=\text { total number of pupils })} \times 100
$$

The data was evaluated and coded separately by two experts. In order to keep the reliability high, the coherence percentage is calculated (Altunay, Oral, \& Yalçınkaya, 2014).

$$
\text { Agreement percentage }=\frac{\text { Coherence Unity }}{\text { Coherence Unity }+ \text { Opinion Difference }} \times 100
$$

Awareness motion: The behavior of the children when they give related answers to the questions asked in the interview about "sustainable built environment".

Unawareness motion: The behavior of the children when they give non attributable answers or thought to be irrelevant to the subject while being interviewed about "sustainable built environment".

Undecided: The behavior of the children when they give answer such as "I don't know" or "I didn't understand" to the questions asked in the interview about "sustainable built environment".

\section{FINDINGS}

The pre-test (interview) administered in context to the "LEED Green Building Certificate System Criteria" data results and evaluations are stated as below.

\section{LEED Certificate Criterion 1 "Sustainable Sites"}

In the LEED Certification System, "sustainable sites" deal with a lot of things, such as the features of the piece of land where the buildings will be constructed (to be distant from the agricultural areas), the distance to the communal common areas (such as post office, hospital, school), roofing systems that have effect on the environment (green roof, etc.) (USBGC, 2014). The children were asked five questions within this criterion in order to be able to measure the level of their awareness. The answers given by the children for the interview questions are shown in Table 3. 
Table 3. "LEED Certificate Criterion 1; Sustainable Sites" table of the level of awareness

\begin{tabular}{|c|c|c|c|c|c|c|}
\hline \multirow{4}{*}{$\begin{array}{c}\text { QUESTIONS } \\
\\
\\
\text { QUESTION } \\
1\end{array}$} & PUP & L'S ANSWERS & MOTIONS & $(\mathbf{n})$ & (\%) & EVALUATION \\
\hline & \multicolumn{2}{|r|}{$\begin{array}{l}\text { A (a playground park that includes imitation materials like plastic, } \\
\text { unnatural and has negative attributes to the environment) }\end{array}$} & $\begin{array}{l}\text { unawareness } \\
\text { motion }\end{array}$ & 76 & 56.71 & \multirow{3}{*}{$\begin{array}{l}\text { In this question it is expected that } \\
\text { environment awareness in children } \\
\text { would choose Picture "B" that } \\
\text { includes natural playground toys and } \\
\text { a playground that's formed where its } \\
\text { nature is untouched. } \\
\text { However, } 43.29 \% \text { of the children } \\
\text { chose this playground park. } \\
\text { Type " } \mathrm{A} \text { " which the children chose is } \\
\text { the playground park type that does } \\
\text { not carry suitable attributes for the } \\
\text { environment. }\end{array}$} \\
\hline & \multicolumn{2}{|r|}{$\begin{array}{l}\text { B (a playground park that is formed of natural materials, } \\
\text { education elements, doesn't include imitating materials that will } \\
\text { have effect on the health of the children and it has positive } \\
\text { attributes towards the environment) }\end{array}$} & $\begin{array}{l}\text { awareness } \\
\text { motion }\end{array}$ & 58 & 43.29 & \\
\hline & \multicolumn{2}{|c|}{ "I don't know" } & undecided & 0 & 0 & \\
\hline \multirow{12}{*}{$\begin{array}{l}\text { QUESTION } \\
2\end{array}$} & \multirow{12}{*}{ A } & "I like & \multirow{6}{*}{$\begin{array}{l}\text { unawareness } \\
\text { motion }\end{array}$} & 32 & \multirow{6}{*}{50.75} & \multirow{12}{*}{$\begin{array}{l}\text { In this question, it identified why the } \\
\text { children chose the playground parks } \\
\text { "A" and " } B \text { ". It was expected that the } \\
\text { children choose the playground park } \\
\text { with attributes that will not show } \\
\text { - harm to him or her or the } \\
\text { environment. However, } 40.30 \% \text { of the } \\
\text { children chose this type of park. This } \\
\text { percentage in this subject shows a } \\
\text { high unaware motion ("I have no } \\
\text { idea" is evaluated as unaware } \\
\text { motion). }\end{array}$} \\
\hline & & "It has & & 31 & & \\
\hline & & "It's a I & & 2 & & \\
\hline & & "It's a & & 1 & & \\
\hline & & "It ha & & 1 & & \\
\hline & & "It's a & & 1 & & \\
\hline & & $\begin{array}{l}\text { "It has } \\
\text { etc." (fo }\end{array}$ & \multirow{5}{*}{$\begin{array}{l}\text { awareness } \\
\text { motion }\end{array}$} & 36 & \multirow{5}{*}{-40.30} & \\
\hline & & "It look & & 8 & & \\
\hline & & "It loo & & 6 & & \\
\hline & & "Ther & & 2 & & \\
\hline & & "It's & & 2 & & \\
\hline & & "I dor & decided & 12 & 8.95 & \\
\hline \multirow{11}{*}{$\begin{array}{l}\text { QUESTION } \\
3\end{array}$} & \multicolumn{2}{|c|}{ "A House" } & \multirow{8}{*}{$\begin{array}{l}\text { unawareness } \\
\text { motion }\end{array}$} & 77 & \multirow{4}{*}{-92.53} & \multirow{11}{*}{$\begin{array}{l}\text { In this question, there is a picture of a } \\
\text { woman building a "green roof". It was } \\
\text { expected that when the children look } \\
\text { at the picture they are aware and } \\
\text { state this. However, } 5.97 \% \text { of the } \\
\text { children perceived the relationship } \\
\text { between the roof and plants that } \\
\text { - there were plants on the roof. This } \\
\text { shows a majority of unaware motion } \\
\text { - about green roofs. }\end{array}$} \\
\hline & \multicolumn{2}{|c|}{ "Human" } & & 7 & & \\
\hline & \multicolumn{2}{|r|}{ people and a house" } & & 19 & & \\
\hline & "A he & ind flowers" & & 2 & & \\
\hline & \multicolumn{2}{|c|}{ "A woman is planting flowers" } & & 7 & 92.53 & \\
\hline & \multicolumn{2}{|c|}{ "There's a woman decorating the roof" } & & $\frac{1}{1}$ & & \\
\hline & \multicolumn{2}{|c|}{ "There's a woman building a house" } & & 8 & & \\
\hline & \multicolumn{2}{|c|}{ "Their picking the leaves" } & & 2 & & \\
\hline & \multicolumn{2}{|c|}{ "A woman planting flowers on the top of the house" } & awareness & 7 & & \\
\hline & \multicolumn{2}{|c|}{ "There are trees on the top of the house" } & motion & 1 & & \\
\hline & "I do & 't know" & undecided & 2 & 1.50 & \\
\hline & "The & " & & 42 & & \\
\hline & "The & nan is planting something's" & & 15 & & \\
\hline & "The & s" & & 13 & & asked what the woman is doing in the \\
\hline & "The & en & ness & 8 & & picture and it is expected that they \\
\hline & "She & & & 2 & & perceive the relationship between the \\
\hline QUESTION & "The & ( & & 1 & & roofa \\
\hline 4 & "The & tan is putting a box on the roof of the house" & & 1 & & However, $29.10 \%$ of the children \\
\hline & "She & imbing the house" & & 1 & & formed this relationship. According to \\
\hline & "The & woman is planting/putting flowers on the roof of the house" & & 37 & & the percentage, it shows a majority of \\
\hline & "She & is building a green roof" & motion & 1 & & \\
\hline & "She & is organizing the roof" & & 1 & & \\
\hline & "I do & 't know" & undecided & 12 & 8.95 & \\
\hline & $\begin{array}{l}\text { NO } \\
\text { term } \\
\end{array}$ & $\begin{array}{l}\text { tates the number of children who have never heard the } \\
\text { "green roof" before) }\end{array}$ & $\begin{array}{c}\text { unawareness } \\
\text { motion }\end{array}$ & 123 & 91.80 & $\begin{array}{l}\text { In this question even though the } \\
\text { children may not know the meaning }\end{array}$ \\
\hline $\begin{array}{l}\text { QUESTION } \\
5\end{array}$ & $\begin{array}{l}\text { YES } \\
\text { meat } \\
\text { who }\end{array}$ & $\begin{array}{l}\text { shows the number of children who may not know the } \\
\text { ing but they have heard the term "green roof" and those } \\
\text { do know) }\end{array}$ & $\begin{array}{l}\text { awareness } \\
\text { motion }\end{array}$ & 11 & 8.20 & $\begin{array}{l}\text { they are asked if they have heard of } \\
\text { the term "green roof" before. } 8.20 \% \\
\text { of the children have heard this term }\end{array}$ \\
\hline & "I do & 't know" & undecided & 0 & 0 & before. \\
\hline
\end{tabular}

Criterion 1 according to the results of general evaluation $25.48 \%$ awareness motion and $70.75 \%$ unawareness motion was compared. It is identified that $3.77 \%$ of the children had no idea (undecided) about the questions asked.

\section{LEED Certificate Criterion 2 "Water Efficiency"}

According to the LEED Certification System, the buildings include general water consumption, consumption reduction (saving), efficient landscape irrigation and innovative water technology systems (Erten, 2011). In this study three interview questions were prepared in order to measure the children's level of awareness towards this type of systems in the buildings. The answers the children gave for the interview questions are seen in Table 4. 
Table 4. "LEED Certificate Criterion 2; Effective Water Use" table of the level of awareness

\begin{tabular}{|c|c|c|c|c|c|}
\hline QUESTIONS & PUPIL'S ANSWERS & MOTION & (n) & (\%) & EVALUATION \\
\hline \multirow{3}{*}{$\begin{array}{l}\text { QUESTION } \\
6\end{array}$} & $\begin{array}{l}\text { NO (states the number of children who have never heard the } \\
\text { term "saving water" before) }\end{array}$ & $\begin{array}{c}\text { unawareness } \\
\text { motion }\end{array}$ & 106 & 79.10 & \multirow{3}{*}{$\begin{array}{l}\text { In this question, the level of awareness } \\
\text { about the saving of the water systems } \\
\text { in the building is measured. In context } \\
\text { it was determined that } 20.9 \% \text { of } \\
\text { children performed "awareness } \\
\text { motion". }\end{array}$} \\
\hline & $\begin{array}{l}\text { YES (shows the number of children who may not know the } \\
\text { meaning but they have heard the term "saving water" and those } \\
\text { who do know) }\end{array}$ & $\begin{array}{l}\text { awareness } \\
\text { motion }\end{array}$ & 28 & 20.90 & \\
\hline & "I don't know" & undecided & 0 & 0 & \\
\hline \multirow{3}{*}{$\begin{array}{l}\text { QUESTION } \\
7\end{array}$} & $\begin{array}{l}\text { NO (states the number of children who have never heard the } \\
\text { term "collecting water" before) }\end{array}$ & $\begin{array}{c}\text { unawareness } \\
\text { motion }\end{array}$ & 103 & 76.86 & \multirow{3}{*}{$\begin{array}{l}\text { In this question, the level of awareness } \\
\text { about the water systems used in the } \\
\text { buildings is measured. In context it } \\
\text { was determined that } 22.38 \% \text { of } \\
\text { children performed "awareness } \\
\text { motion". }\end{array}$} \\
\hline & $\begin{array}{l}\text { YES (shows the number of children who may not know the } \\
\text { meaning but they have heard the term "saving water" and those } \\
\text { who do know) }\end{array}$ & $\begin{array}{l}\text { awareness } \\
\text { motion }\end{array}$ & 30 & 22.38 & \\
\hline & "I don't know" & undecided & 1 & 0.76 & \\
\hline \multirow{17}{*}{$\begin{array}{l}\text { QUESTION } \\
8\end{array}$} & "They are pouring the water" & \multirow{14}{*}{$\begin{array}{l}\text { unawareness } \\
\text { motion }\end{array}$} & 32 & \multirow{14}{*}{59.70} & \multirow{17}{*}{$\begin{array}{l}\text { In the picture of this question the } \\
\text { children are experimenting in the } \\
\text { school environment how to collect } \\
\text { rain water on the roof of the building. } \\
\text { It is expected that the children form a } \\
\text { relationship between the roof of the } \\
\text { building, rain water and a bucket } \\
\text { where the answers will be evaluated } \\
\text { according to the context. In this } \\
\text { question, } 28.35 \% \text { of the children } \\
\text { answered close to expected. }\end{array}$} \\
\hline & "They are building houses" & & 11 & & \\
\hline & "They are watering the roof" & & 7 & & \\
\hline & "They are making a joke/game" & & 6 & & \\
\hline & "They are cleaning the roof" & & 6 & & \\
\hline & "They are emptying the water in a bucket" & & 4 & & \\
\hline & "They are saving water" & & 4 & & \\
\hline & "They are watering some things" & & 3 & & \\
\hline & "They are painting the roof" & & 2 & & \\
\hline & "He/she is helping their mum" & & 1 & & \\
\hline & "They are filling the air with water" & & 1 & & \\
\hline & "They are painting" & & 1 & & \\
\hline & "They are working" & & 1 & & \\
\hline & "They are pouring water" & & 1 & & \\
\hline & "Someone is pouring the water the other is emptying the bucket" & \multirow{2}{*}{$\begin{array}{l}\text { awareness } \\
\text { motion }\end{array}$} & 30 & \multirow{2}{*}{28.35} & \\
\hline & "They are saving water" & & 8 & & \\
\hline & "I don't know" & undecided & 16 & 11.95 & \\
\hline
\end{tabular}

Criterion 2 according to the results of general evaluation $23.87 \%$ awareness motion and $71.88 \%$ unawareness motion was compared. It is identified that $4.25 \%$ of the children had no idea (undecided) about the questions asked.

\section{LEED Certificate Criterion 3 "Energy Efficiency"}

A lot of importance is given to the subjects; Renewable energy sources and efficient use of energy in the buildings (Dikmen, 2011). This is also true according to the LEED Certificate. In context to this criterion, the children were asked four questions in order to measure their level of awareness towards effective energy use and renewable energy resources. The results are seen in Table 5. 
Table 5. "LEED Certificate Criterion 3; Effective Energy Use" table of the level of awareness

\begin{tabular}{|c|c|c|c|c|c|}
\hline QUESTIONS & PUPIL'S ANSWERS & MOTIONS & (n) & (\%) & EVALUATION \\
\hline \multirow{3}{*}{$\begin{array}{l}\text { QUESTION } \\
\quad 9\end{array}$} & $\begin{array}{l}\text { NO (states the number of children who have never seen or heard } \\
\text { of a "wind turbine") }\end{array}$ & $\begin{array}{c}\text { unawareness } \\
\text { motion }\end{array}$ & 96 & 71.6 & \multirow{3}{*}{$\begin{array}{l}\text { In this question, it is measured } \\
\text { whether the children recognize the } \\
\text { wind turbine shown in picture (A). } \\
\text { When the answers were analyzed } \\
25.37 \% \text { of the children have heard or } \\
\text { seen a wind turbine. }\end{array}$} \\
\hline & $\begin{array}{l}\text { YES (states the number of children who may not know the exact } \\
\text { name but they have seen or heard of the word "wind turbine" ) }\end{array}$ & $\begin{array}{c}\text { awareness } \\
\text { motion }\end{array}$ & 34 & 25.37 & \\
\hline & "I don't know" & undecided & 4 & 2.99 & \\
\hline \multirow{3}{*}{$\begin{array}{l}\text { QUESTION } \\
10\end{array}$} & $\begin{array}{l}\text { NO (states the number of children who have never seen or heard } \\
\text { of "solar panels") }\end{array}$ & $\begin{array}{c}\text { unawareness } \\
\text { motion }\end{array}$ & 113 & 84.3 & \multirow{3}{*}{$\begin{array}{l}\text { In this question, it is measured } \\
\text { whether the children recognize the } \\
\text { solar panels shown in picture (A). } \\
\text { When the answers were analyzed } \\
13.43 \% \text { of the children have heard or } \\
\text { seen solar panels. }\end{array}$} \\
\hline & $\begin{array}{l}\text { YES (states the number of children who may not know the exact } \\
\text { name but they have seen or heard the word "solar panels") }\end{array}$ & $\begin{array}{l}\text { awareness } \\
\text { motion }\end{array}$ & 18 & 13.43 & \\
\hline & "I don't know" & undecided & 3 & 2.25 & \\
\hline \multirow{3}{*}{$\begin{array}{l}\text { QUESTION } \\
11\end{array}$} & $\begin{array}{l}\text { NO (states the number of children who have never known how } \\
\text { the "solar panels" or "wind turbine" works, where it is used or } \\
\text { what it's useful for) }\end{array}$ & $\begin{array}{l}\text { unawareness } \\
\text { motion }\end{array}$ & 120 & 89.5 & \multirow{3}{*}{$\begin{array}{l}\text { In this question, awareness level of the } \\
\text { children was measured on the } \\
\text { usefulness of the two important pieces } \\
\text { of the solar panels and wind turbines. } \\
\text { When the answers were analyzed } \\
10.45 \% \text { of children show awareness } \\
\text { about the use of solar panels and wind } \\
\text { turbines. }\end{array}$} \\
\hline & $\begin{array}{l}\text { YES ("states the number of children who can at least make a } \\
\text { comment in context who don't know how the solar panels or } \\
\text { wind turbines work, where they are used or what it's useful for) }\end{array}$ & $\begin{array}{l}\text { awareness } \\
\text { motion }\end{array}$ & 14 & 10.4 & \\
\hline & "I don" & ur & 0 & 0 & \\
\hline \multirow{3}{*}{$\begin{array}{l}\text { QUESTION } \\
12\end{array}$} & $\begin{array}{l}\text { NO (states the number of children who do not understand the } \\
\text { relationship between renewable energy resources and the } \\
\text { building) }\end{array}$ & $\begin{array}{l}\text { unawareness } \\
\text { motion }\end{array}$ & 126 & 94. & \multirow{3}{*}{$\begin{array}{l}\text { In this question, it is measured } \\
\text { whether the children recognize or not } \\
\text { as in picture (B) of a building that } \\
\text { receives its energy from solar panels } \\
\text { and wind turbines. When the answers } \\
\text { were analyzed } 5.97 \% \text { of the children } \\
\text { have heard or seen buildings with } \\
\text { renewable energy resources. }\end{array}$} \\
\hline & $\begin{array}{l}\text { YES (states the number of children who relates and speaks about } \\
\text { or tries to speak a lot about renewable energy resources and } \\
\text { buildings) }\end{array}$ & $\begin{array}{l}\text { awareness } \\
\text { motion }\end{array}$ & 8 & 5.97 & \\
\hline & "I don't know" & undecided & 0 & 0 & \\
\hline
\end{tabular}

Criterion 3 according to the results of general evaluation, $13.80 \%$ awareness motion and $84.88 \%$ unawareness motion was compared. It is identified that $4.25 \%$ of the children had no idea (undecided) about the questions asked.

\section{LEED Certificate Criterion 4 "Evaluation of Waste Materials"}

It is impossible to create a world with no waste. Therefore, it is very important how the wastes will be evaluated. Effective use of materials is an important topic today for not just at the premises, but in waste recycling and recycling in all areas (Özburak, 2017). The LEED certificate shows coherence to this criterion. Under this heading five questions were asked to the children in order to measure their awareness level. The results are as seen on Table 6.

Criterion 4, according to the results of general evaluation $13.87 \%$ awareness motion and $78.05 \%$ unawareness motion was compared. It is identified that $8.08 \%$ of the children had no idea (undecided) about the questions asked. 
Table 6. "LEED Certificate Criterion 4; "Evaluation of Waste Materials" table of the level of awareness

\begin{tabular}{|c|c|c|c|c|c|}
\hline QUESTIONS & PUPIL'S ANSWERS & MOTIONS & (n) & (\%) & EVALUATION \\
\hline \multirow{4}{*}{$\begin{array}{l}\text { QUESTION } \\
13\end{array}$} & "Waste bin" & \multirow{2}{*}{$\begin{array}{c}\text { unawareness } \\
\text { motion }\end{array}$} & 132 & \multirow{2}{*}{99.25} & \multirow{4}{*}{$\begin{array}{l}\text { In this question, children's level of } \\
\text { awareness about waste is measured. } \\
\text { It was stated that } 99.25 \% \text { of the } \\
\text { children do not mention about waste } \\
\text { bins or recycle bins, or even } \\
\text { reusable. }\end{array}$} \\
\hline & "Fields" & & 1 & & \\
\hline & \multirow[t]{2}{*}{ Recycle bins (paper, glass, general house waste etc.) } & $\begin{array}{c}\text { awareness } \\
\text { motion }\end{array}$ & 0 & 0 & \\
\hline & & undecided & 1 & 0.75 & \\
\hline \multirow{12}{*}{$\begin{array}{l}\text { QUESTION } \\
14\end{array}$} & "To the dump" & \multirow{8}{*}{$\begin{array}{l}\text { unawareness } \\
\text { motion }\end{array}$} & 26 & \multirow{8}{*}{63.43} & \multirow{12}{*}{$\begin{array}{l}\text { It was mentioned to the children that } \\
\text { wastes are thrown in the bins, in this } \\
\text { question asking where the wastes } \\
\text { are taken obtained more detailed } \\
\text { answers. } 12.68 \% \text { of the children } \\
\text { mentioned about wastes being } \\
\text { evaluated through "recycle" and } \\
\text { "waste factory" systems. }\end{array}$} \\
\hline & "Waste trucks" & & 25 & & \\
\hline & "Waste bin" & & 19 & & \\
\hline & "Dustbin men collect it" & & 11 & & \\
\hline & "To the municipality" & & 1 & & \\
\hline & "To the sea" & & 1 & & \\
\hline & "To the earth" & & 1 & & \\
\hline & "Gas machine" & & 1 & & \\
\hline & "Waste factory" & \multirow{3}{*}{$\begin{array}{l}\text { awareness } \\
\text { motion }\end{array}$} & 5 & \multirow{3}{*}{12.68} & \\
\hline & "Waste machines" & & 2 & & \\
\hline & "Recycle" & & 10 & & \\
\hline & "I don't know" & undecided & 32 & 23.89 & \\
\hline \multirow{3}{*}{$\begin{array}{l}\text { QUESTION } \\
15\end{array}$} & NO (states the number of children who will never reuse waste) & $\begin{array}{l}\text { unawareness } \\
\text { motion }\end{array}$ & 86 & 64.17 & \multirow{3}{*}{$\begin{array}{l}\text { In this question the children were ask } \\
\text { - the usability of waste. } 34.32 \% \\
\text { average of the children is thinking } \\
\text { - that wastes can somehow be usable. }\end{array}$} \\
\hline & $\begin{array}{l}\text { YES(states the number of children who will reuse or recycle } \\
\text { waste) }\end{array}$ & $\begin{array}{c}\text { awareness } \\
\text { motion }\end{array}$ & 46 & 34.32 & \\
\hline & "I don't know" & undecided & 2 & 1.51 & \\
\hline \multirow{22}{*}{$\begin{array}{l}\text { QUESTION } \\
16\end{array}$} & "Non are usable" & \multirow{11}{*}{$\begin{array}{l}\text { unawareness } \\
\text { motion }\end{array}$} & 72 & \multirow{11}{*}{64.17} & \multirow{22}{*}{$\begin{array}{l}\text { It is important that the refuse from } \\
\text { the buildings are separated and are } \\
\text { either recycled or reused. The } \\
\text { question "If we were to reuse the } \\
\text { waste which ones would we use?" } \\
\text { was asked to the children. According } \\
\text { to the various answers obtained } \\
\text { from the children show that } 21.64 \% \\
\text { average say "sustainable" principles } \\
\text { are suitable. }\end{array}$} \\
\hline & "New ones" & & 3 & & \\
\hline & "Clean ones" & & 2 & & \\
\hline & "Empty ones" & & 2 & & \\
\hline & "Odorless" & & $\overline{1}$ & & \\
\hline & "Toys that drop on the floor" & & 1 & & \\
\hline & "Non-creased ones" & & 1 & & \\
\hline & "Those on the floor" & & 1 & & \\
\hline & "Those we need" & & 1 & & \\
\hline & "Those that are full" & & $\frac{1}{1}$ & & \\
\hline & "Those that can be opened" & & 1 & & \\
\hline & "Papers" & \multirow{10}{*}{$\begin{array}{l}\text { awareness } \\
\text { motion }\end{array}$} & 14 & \multirow{10}{*}{21.64} & \\
\hline & "Bottles" & & 3 & & \\
\hline & "Plastics" & & 2 & & \\
\hline & "Plastics and papers" & & 2 & & \\
\hline & "Other recyclables" & & 2 & & \\
\hline & "Glass" & & 2 & & \\
\hline & "Glass and metals" & & 1 & & \\
\hline & "Bottles and cans" & & $\overline{1}$ & & \\
\hline & "Carton and paper" & & 1 & & \\
\hline & "Paper and bottles" & & 1 & & \\
\hline & "I don't know" & undecided & 19 & 14.19 & \\
\hline \multirow{3}{*}{$\begin{array}{l}\text { QUESTION } \\
17\end{array}$} & $\begin{array}{l}\text { NO (states the number of children who clearly do not understand } \\
\text { or cannot explain in the given picture what the children are doing } \\
\text { "compost") }\end{array}$ & $\begin{array}{l}\text { unawareness } \\
\text { motion }\end{array}$ & 133 & 99.25 & \multirow{3}{*}{$\begin{array}{l}\text { It was measured whether the } \\
\text { children are aware of the process of } \\
\text { the children in the picture that they } \\
\text { are doing "compost" or not. } \\
\text { However, it is stated that } 0.75 \% \\
\text { average of the children can form a } \\
\text { relationship with recycling and } \\
\text { explain it. }\end{array}$} \\
\hline & $\begin{array}{l}\text { YES(states the number of children who can at least understand or } \\
\text { is aware of the relationship with recycling given in the picture of } \\
\text { the children doing "compost") }\end{array}$ & $\begin{array}{l}\text { awareness } \\
\text { motion }\end{array}$ & 1 & 0.75 & \\
\hline & "I don't know" & undecided & 0 & 0 & \\
\hline
\end{tabular}

\section{DISCUSSION}

Even though "architectural profession" may appear as an area within itself, the context of environmental education is a topic that should meet all individuals in the society. Because every individual in the society is the decision maker or practitioner on the built environment (Arın, 2014). People spend most of their day in built environments such as work place, school, residence, etc type of buildings. The World Health Organization (WHO) data also supports that humans spend $90 \%$ of their time in buildings, $70 \%$ of this in the work environment and $20 \%$ at home (Zeydan, Zeydan \& Yilmaz, 2009). For this reason, it is important that they know the whole process from the construction of the building until the usage. The buildings should be explained to users (individuals) and 


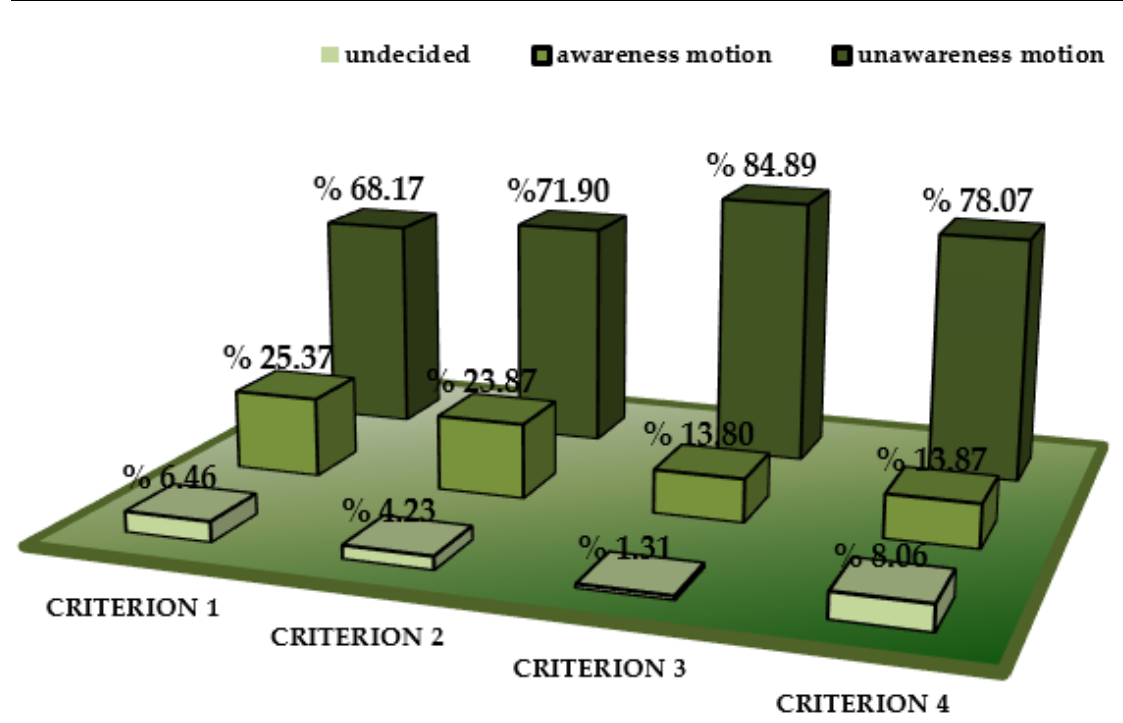

Figure 2. Table of "Sustainable built environment" awareness level of preschool children according to the LEED criteria's

"sustainable built environment awareness" should be formed so people have the right of speech when forming indoor environments, high quality, create life with respect to nature therefore it will form a protection towards the environment.

It will ensure the children in the preschool period to notice their environment, form space perceptions and recognize their built environment which they live in. Built environmental education activities include 3D. Thus strengthening the relationship of children with their physical surroundings, as well as in acquiring skills such as interrogation, relationships between systems and problem solving (Acer, 2016). It also allows for the development of coarse and fine motor movements, such as running, jumping, walking, holding, pushing, and cognitive skills, such as building relationships with the social environment, thinking scientifically, developing aesthetic perception (Gülay, 2011). Looking at the education curriculum in the preschool period it is seen that when environment education is mentioned it only includes "natural environment" elements. According to the study administered by Hedefalk, Almqvist, and Östman (2015), 87 scientific articles were analyzed and these studies focused on "natural environment", it can be clearly seen that built environment has not yet been included in education. In context, the Ministry of Education must review and renew the curriculum (Gülay \& Ekici, 2010).

There are a number of scientific studies highlighting the importance of environmental education in children. Beginning in the nineties, the importance given to children's awareness of the environment and their awareness has also been reflected in the work done in this area. Lieflander, Fröhlich, Bogner, and Schultz (2013) has studied the importance of environmental education, especially the environmental education, in examining the significance and future impacts on children. On the other hand, Wilson (2010) conducted a comparative study on "Environmental Education Programs for Preschool Pupils" which put forth common aspects of nine different contents of educational programs. It is clear that in this study, natural environment education is put forward and the programs do not cover "built environment education".

\section{CONCLUSION}

This study was administered after identifying the deficiency of "environment education" in the preschool curriculum. In the study, it can be seen in the current education curriculum that the children are not able to form a connection between the buildings and natural environment (total "unawareness motion $(75.75 \%)+$ undecided $(5.03 \%)$ " $=80.78 \%$ ). During the interviews while showing pictures, it is apparent that the children do not have sufficient amount of awareness about the use of the types of alternative energy resources green roof $(8.20 \%)$, collecting of water using buildings (22.38\%) and solar panels (13.43\%). According to the LEED Green Building Certificate System criteria's the results of seventeen interview questions can be seen in Figure 2.

When interviews with children were examined in the context of sustainability criteria, it was found that children were aware that they had very little awareness (\% 19.22) and that some children did unawareness motion (\% 75.75) when they used houses, and (5.03) of them had no idea about sustainable built environment (see Figure 3). 


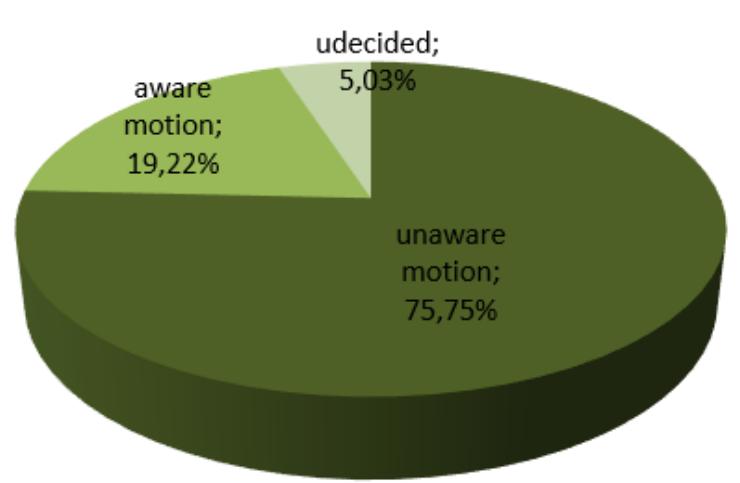

Figure 3. Children's "sustainable built environment" consciousness level in pre-school period

According to the results of the study in the preschool period it is compulsory that the environment education curriculum must be developed. The integration of curriculum in education, which will raise awareness about the buildings in which the children live and use, is important for the protection of the environment. The following are the fundamentals that can be suggested for preschool period environment lesson content.

- Environmental lesson should be organized as "natural environment" and "built environment"

- The preschool curriculums should be checked and a program of awareness towards renewable energy resources, green roof and collecting water/effective system use should be formed otherwise this deficiency should be resolved.

- The curriculum that will be prepared should not be under one perspective but a collective study with experts within this field such as architect, pedagogue and preschool teacher.

\section{ACKNOWLEDGEMENT}

This study of "In the Education period of Preschool "Sustainable Living Environment" Practice" has been prepared in scope of Scientific Research Project (BAP). The project has been financed by Near East University Scientific Research Coordination Unit.

\section{REFERENCES}

Acer, D. (2016). Çocuk ve Mimarlık: Küçük Çocuklar İçin Mimari Tasarım Öğretim Programı [in Turkish]. Hacettepe Üniversitesi Ĕ̆itim Fakültesi Dergisi, 30(1), 66-81. https:/ / doi.org/10.16986/HUJE.2015014659

Altunay, E., Oral, G., \& Yalçınkaya, M. (2014). Eğitim Kurumlarında Mobbing Uygulamalarına İlişkin Nitel Bir Araştırma [in Turkish]. Sakarya Üniversitesi Eğitim Dergisi, 4(1), 62-68.

Arın, S. (2014). Built Environment Education For Children Through Architectural Workshops. Procedia - Social and Behavioral Sciences, 143, 35-39. https:/ / doi.org/10.1016/j.sbspro.2014.07.353

Basile, C. G. (2000). Environmental education as a catalyst for transfer of learning in young children. The Journal of Environmental Education, 32(1), 21-27. https:/ / doi.org/10.1080/00958960009598668

Böke, K. (2009). Sosyal Bilimlerde Araştırma Yöntemleri [in Turkish]. In O. Ö. Demir (Yay. Haz.) Nitel Araştırma Yöntemleri (pp. 285-318). İstanbul: Alfa Yayınevi.

Cooper, A. (2015). Nature and the Outdoor Learning Environment: The Forgotten Resource in Early Childhood Education. International Journal of Early Childhood Environmental Education, 3(1), 85-97.

Çukur, D. \& Özgüner, H. (2008). Kentsel Alanda Çocuklara Doğa Bilinci Kazandırmada Oyun Mekanı Tasarımının Rolü [in Turkish]. Süleyman Demirel Üniversitesi Orman Fakültesi Dergisi, 2(0), 177-187.

Çukur, D. (2011). Okul Öncesi Çocukluk Döneminde Sağlıklı Gelişimi Destekleyici Dış Mekan Tasarımı [in Turkish]. Süleyman Demirel Üniversitesi Orman Fakültesi Dergisi, 12(1), 70-76.

Dikmen, Ç. B. (2011). Enerji Etkin Yapı Tasarım Ölçütlerinin Örneklenmesi [in Turkish]. Politeknik Dergisi, 14(2), 121-134. https:// doi.org/10.2339/2011.14.2

Erdoğan, N. I., \& Canbeldek, M. (2017). Erken Çocukluk Eğitiminde Ölçme ve Değerlendirme [in Turkish]. Abant İzzet Baysal Üniversitesi Eğitim Fakültesi Dergisi, 17(3), 1306-1327. https:/ / doi.org/10.17240/aibuefd.2017.17.31178-338827 
Erten, D. (2011). Sürdürülebilir Üretim Ve Tüketim Yayınları - V, Yeşil Binalar [in Turkish]. Ankara: Sürdürülebilir Üretim ve Tüketim Yayınları.

Erten, S. (2004). Çevre Egitimi Ve Çevre Bilinci Nedir, Çevre Egitimi Nasıl Olmalıdır? [in Turkish] Çevre ve İnsan Dergisi: Çevre ve Orman Bakanlıg Yayın Organı, 65/66, 1-13.

Esa, N. (2010). Environmental knowledge, attitude and practices of student teachers. International Research in Geographical and Environmental Education, 19(1), 39-50. https:/ / doi.org/10.1080/10382040903545534

Gökmen, H. (2010). Mimarlık ve Çocuk Çalışmaları: Yapılı Çevre Eğitimi [in Turkish]. Mimarlık Dergisi, 352(2), $76-$ 79.

Green, C. J. (2015). Toward Young Children as Active Researchers: A Critical Review of -the Methodologies and Methods in Early Childhood Environmental Education. The Journal of Environmental Education, 46(4), 207229. https:/ / doi.org/10.1080/00958964.2015.1050345

Gülay, H. (2011). Ağaç Yaş İken Eğilir: Yaşamın İlk Yıllarında Çevre Eğitiminin Önemi. TÜBAV Bilim Dergisi, 4(3), 240-245.

Gülay, H., \& Ekici, G. (2010). MEB Okul Öncesi Eğitim Programının Çevre Eğitimi Açısından Analizi [in Turkish]. Türk Fen Eğitimi Dergisi, 7(1), 74-84.

Gülay, H., \& Öznacar, M. D. (2010). Okul Öncesi Dönem Çocukları İçin Çevre Eğitimi Etkinlikleri [in Turkish]. Ankara: Pegem Akademi.

Gündem Kıbrıs Gazetesi (11 Feb, 2015). “Enerji ve Çevre, Bilinçli Çocuklar Projesi” tanıtıldı [in Turkish]. Retrieved from https://www.gundemkibris.com/mansetler/enerji-ve-cevre-bilincli-cocuklar-projesi-tanitildih106114.html

Gürbüz, S., \& Şahin, F. (2014). Araştırma Yöntemleri (2. Ed.) [in Turkish]. Ankara: Seçkin Yayıncılık

Hedefalk, M., Almqvist, J., \& Östman, L. (2015). Education for sustainable development in early childhood education: a review of the research literature. Environmental Education Research, 21(7), 975-990. https:/ / doi.org/10.1080/13504622.2014.971716

İslamoğlu, Ö. (2017). Interaction Between Educational Approach and Space: The Case of Montessori. EURASIA Journal of Mathematics, Science and Technology Education, 14(1), 265-274. https://doi.org/10.12973/ejmste/79799

Kahriman-Ozturk, D., Olgan, R., \& Guler, T. (2012). Preschool Children's Ideas on Sustainable Development: How Preschool Children Perceive Three Pillars of Sustainability with the Regard to 7R. Educational Sciences: Theory and Practice, 12(4), 2987-2995.

Kahyaoğlu, M., \& Yetişir, M. İ. (2015). Doğa Kavramı ve Çocukların Doğadan Uzaklaşmasına İlişkin Fenomenografik Bir Çalışma [in Turkish]. Eğitim ve Bilim, 40(182), 159-170. https:/ / doi.org/10.15390/EB.2015.4899

Kavak, Ş., \& Coşkun, H. (2017). Erken Çocukluk Eğitiminde Eğitici Materyal Geliştirmenin Önemi [in Turkish]. Uluslararası Erken Çocukluk Eğitimi Çalışmaları Dergisi, 2(2), 11-23

Klaar, S., \& Öhman, J. (2014). Children's meaning-making of nature in an outdoor-oriented and democratic Swedish preschool practice. European Early Childhood Education Research Journal, 22(2), 229-253. https:// doi.org/10.1080/1350293X.2014.883721

Lieflander, A. K., Fröhlich, G., Bogner, F. X., \& Schultz, W. (2013). Promoting connectedness with nature through environmental education. Environmental Education Research, 19(3), 370-384. https:/ / doi.org/10.1080/13504622.2012.697545

Miller, D. L. (2007). The Seeds of Learning: Young Children Develop Important Skills Through Their Gardening Activities at a Midwestern Early Education Program. Applied Environmental Education \& Communication, 6(1), 49-66. https:/ / doi.org/10.1080/15330150701318828

Musser, L. M., \& Diamond, K. E. (1999). The Children's Attitudes Toward the Environmental Scale for Preschool Child. The Journal of Environmental Education, 30(2), 23-30. https:/ / doi.org/10.1080/00958969909601867

Nikolaeva, S. N. (2008) The Ecological Education of Preschool Children. Russian Education E Society, 50(3), 64-72. https:/ / doi.org/10.2753/RES1060-9393500306

Özburak, Ç. (2017). Ekolojik Okul Öncesi Ĕ̆̈itim Merkezlerinin Tasarım Kriterlerinin Belirlenmesi: Yakın Doğu Okul Öncesi Eğitim Merkezi Örneği [in Turkish]. Saarbrücken: LAP-Lambert Academic Publishing.

Özdemir, O. (2007). Yeni Bir Çevre Eğitimi Perspektifi: “Sürdürülebilir Gelişme Amaçlı Eğitim” [in Turkish]. Ĕ̆itim ve Bilim Dergisi, 32(145), 23-39. 
Sarı, S. Ç. (2011). Çocuk Oyun ve Öğrenme. Eğitime Bakış [in Turkish]. Eğitim-Öğretim ve Bilim Araştırma Dergisi, 20(2), 21-25.

Sontay, G., Gökdere, M., \& Usta, E. (2014). The Study of Scale Developing Related to the Environmental Literacy Component on the Secondary School Level. Necatibey Faculty of Education Electronic Journal of Science and Mathematics Education, 9(1), 49-80.

Tandoğan, O. (2014). Çocuk İçin Daha Yaşanılır Bir Kentsel Mekan: Dünyada Gerçekleştirilen Uygulamalar [in Turkish]. Megaron Dergisi, 9(1), 19-33. https:/ / doi.org/10.5505/MEGARON.2014.43534

Taşkın, Ö., \& Şahin, B. (2008). "Çevre” Kavramı ve Altı Yaş Okul Öncesi Çocuklar [in Turkish]. Pamukkale Üniversitesi Ĕ̆itim Fakültesi Dergisi, 1(23), 1-12.

USGBC. (2014). LEED v4 for Building Design and Construction. Retrieved from https:/ / www.usgbc.org/resources/leed-v4-building-design-and-construction-current-version

Warburton, K. (2003). Deep learning and education for sustainability. International Journal of Sustainability in Higher Education, 4(1), 44-56. https:/ / doi.org/10.1108/14676370310455332

Wilson, R. (2010). Environmental Education Programs for Preschool Children. The Journal of Environmental Education, 27(4), 28-33. https:/ / doi.org/10.1080/00958964.1996.9941473

Zeydan, Z. E., Zeydan, Ö., \& Yıldırım, Y. (2009). Hasta Bina Sendromu [in Turkish]. IX. Ulusal Tessisat Mühendisliği Kongresi Bildiri Kitapçı̆̆̆ (pp. 587-595).

\section{http://www.ejmste.com}

